\title{
Epidemiological study of hard metal asthma
}

\author{
Y Kusaka, M Iki, S Kumagai, S Goto
}

\begin{abstract}
Objectives-To elucidate factors contributing to hard metal asthma, the entire workforce of a corporation producing hard metal tools $(n=703)$ was examined. Methods-The variables evaluated were the atopy reflected by immunoglobulin $E$ (IgE) antibody against mite allergen, history of exposure to hard metal, smoking, concentration of airborne cobalt, specific IgE antibody reaction against cobalt, and the respiratory symptom of attacks of reversible dyspnoea with wheeze (asthmatic symptoms).
\end{abstract}

Results-Univariate analysis showed that the prevalence of the asthmatic symptoms was significantly higher in formerly and currently exposed male workers than in non-exposed male workers. Positive IgE reaction against cobalt was found in seven men $(2 \cdot 0 \%)$, all of whom had asthmatic symptoms. Furthermore, it was found that atopy, positive IgE antibody against cobalt, and age of $\mathbf{4 0}$ or older were significantly correlated with asthmatic symptoms. Multilogistic analysis on the same factors and smoking in all of the workers showed that the age, experience of hard metal exposure, and atopy were significant risk factors associated with the asthmatic symptoms. Multilogistic analysis of data for currently exposed and nonexposed workers also showed that age and atopy were risk factors, and that the exposure to cobalt at the low concentration (at or below $50 \mu \mathrm{g} / \mathrm{m}^{3}$ ) but not at the higher concentration was a significant risk factor. Exposure to mist of coolants containing ionic cobalt, used during grinding, was not found to be any more hazardous in terms of onset of asthmatic symptoms than exposure to hard metal dust containing metallic cobalt.

Conclusions-Accordingly, it is concluded that both environmental factors and individual susceptibility should be taken into consideration in efforts to reduce the prevalence of hard metal asthma.

(Occup Environ Med 1996;53:188-193)

Keywords: hard metal, asthma, cobalt

Exposure to hard metal is known to cause interstitial pneumonia, pulmonary fibrosis, and asthma (hard metal asthma) among workers. ${ }^{1-4}$ Moreover, we have also found evidence of type I hypersensitivity mediated by specific immunoglobulin E (IgE) antibody against cobalt conjugated to human serum albumin (IgE-Co) in some cases of hard metal asthma. ${ }^{5}$

Coates et al first reported the prevalence of occupational asthma $(0.6 \%)$ at an American hard metal plant. ${ }^{3}$ We subsequently reported that the prevalence of hard metal asthma diagnosed by clinical and physiological findings was $5 \cdot 6 \%$ at a Japanese hard metal plant. ${ }^{4}$ After that cross sectional study, the cumulative incidence of hard metal asthma found during a nine year prospective study (1981-9) was $3.6 \%(9 / 241)$ in newly recruited workers. Studies of asthma at French hard metal plants, ${ }^{7}$ chest tightness at a Swedish hard metal plant, ${ }^{8}$ and work related wheeze at American hard metal corporations have also been compared with concentrations of airborne cobalt. ${ }^{9}$

As well as hard metal asthma, there were reports of cases of asthma related to cobalt among diamond polishing workers in Belgium whose work involved the use of a diamondcobalt disc. ${ }^{111}$ Thereafter, in Belgium, three field surveys carried out at diamond polishing workshops, ${ }^{12}$ a plant producing cobalt saws, ${ }^{13}$ and a cobalt refinery plant ${ }^{14}$ examined ventilatory function and respiratory symptoms in association with cobalt. As early as 1980 , there was a report ${ }^{15}$ on cases of asthma induced by cobalt at a Finnish cobalt production plant, which suggested an association between respiratory disorders with cobalt exposure.

We conducted an occupational hygiene study that showed that hard metal asthma may occur even at concentrations of airborne cobalt of less than $50 \mu \mathrm{g} / \mathrm{m}^{3}$, (the current exposure limit in many developed countries including Japan). ${ }^{46}$ Sjögren et $a l^{16}$ found only one case of hard metal asthma during a period of 10 years in Swedish hard metal plants: a man employed in grinding sintered hard metal tools associated with exposure to cobalt at a maximum of $10 \mu \mathrm{g} / \mathrm{m}^{3}$. They thus speculated that ionised cobalt, dissolved in coolants used in grinding of hard metal tools, may be more causative of hard metal asthma than metallic cobalt. As well as these environmental factors, our immunological studies of cases of hard metal asthma showed that not only sensitisation to cobalt but also individual susceptibility (atopy) was involved in hard metal asthma. ${ }^{56}$

Thus, the purpose of the present epidemiological study was to elucidate both individual and environmental factors relating to hard 
Table 1 Characteristics of subjects

\begin{tabular}{lll}
\hline Sex & $n(\%)$ & Age mean $(S D$, range $)$ \\
\hline Men & $583(83)$ & $38 \cdot 4(10 \cdot 8,18-69)$ \\
Women & $120(17)$ & $34 \cdot 0(11 \cdot 7,18-64)$ \\
\hline
\end{tabular}

metal asthma. For this epidemiological purpose, the respiratory symptom of attacks of reversible dyspnoea with wheeze, rather than clinically defined hard metal asthma, was chosen as a health effect indicator of exposure to hard metals.

\section{Subjects and methods}

At the time of this cross sectional study, conducted in 1987, there was a total of 703 workers at the three plants of the hard metal corporation studied (table 1). All of them were the subjects of the present study. They were interviewed regarding their history of exposure to hard metal, smoking, and respiratory symptoms by trained health staff using the Japanese version 17 of the British Medical Research Council (MRC) respiratory questionnaire (1960). ${ }^{18}$ Smoking habit (non-, ex-, and current smoker) was defined as recommended by the MRC. The symptom attacks of reversible dyspnoea with wheeze (positive response to both questions $10 \mathrm{a}$ and $\mathrm{b}$ of the questionnaire) was defined as asthmatic symptoms.

The manufacture of hard metal involves mixing powder, pressing, sintering, shaping, and grinding, as described previously. ${ }^{4}$ Workers involved in grinding are exposed mainly to the mist of coolants in which cobalt is dissolved and ionised, whereas the other workers are exposed to dust of hard metals including metallic cobalt. Thus, the hard metal workers can be classified into two groups according to the chemical form of the cobalt to which they were exposed.

The concentrations of cobalt in the breathing zone were assessed for all of the workers currently exposed to hard metal by personal sampling measured by atomic absorption spectrophotometry. ${ }^{4}$ Air samples were taken on at least two different working days from each worker within one year after the start of the present study, and the arithmetic mean of the concentrations of airborn cobalt was calculated as the representative value for the present daily exposure.

Venous blood was drawn from each subject. The serum samples were measured with a commercial kit (Phadebas, Pharmacia, Sweden) for specific IgE antibody against mite allergen (Dermatophagoides pterioni), which is one of the most common inhalant allergens in Japan. People with a radioallergosorbent test (RAST) score of two or more calculated from IgE titres were considered to be atopic. Specific IgE-Co was also measured in the serum and the RAST score of IgE-Co was calculated as reported previously. ${ }^{5}$

The significance of the differences between groups in the frequency of categorical variables was evaluated by the $\chi^{2}$ test, and a significant association was accepted at $\mathrm{P}<0.05$.
Multilogistic analysis was conducted for asthmatic symptoms on various independent variables, in which case $P<0.05$ was used as a cut off for selection of the variables. All of the statistical analyses were performed by SAS procedures. ${ }^{19}$

\section{Results}

RELATION BETWEEN AGE AND ASTHMATIC SYMPTOMS

Table 2 shows the ages of men and women in age decades and the prevalence of asthmatic symptomss in each age group. The prevalences significantly differed in different age groups in men, but no similar tendency was found in women. It seems (table 2) that the prevalence of asthmatic symptoms in men increases after the age of 40 . Thus, men were divided into two groups: 40 years or over and under 40 years. The prevalence of asthmatic symptoms in men aged 40 or older (37/262, $14.1 \%$ ) was significantly higher than that in those younger than $40(20 / 311,6.4 \%)$. In women, no significant difference was found between the two age groups $(10.9 \%$ in those of 40 or older and $8.2 \%$ in the younger age group).

\section{RELATION BETWEEN SMOKING AND ASTHMATIC SYMPTOMS}

Table 3 shows the prevalences of asthmatic symptoms among male and female hard metal workers grouped by smoking. The prevalence of asthmatic symptoms was highest among the male exsmokers, and that in the current smokers was slightly higher than that in the

\begin{tabular}{ccc} 
Table 2 & Prevalence of asthmatic symptoms by age strata \\
\hline $\begin{array}{l}\text { Sex and } \\
\text { age strata }\end{array}$ & $n(\%)$ & $\begin{array}{l}\text { People with asthmatic } \\
\text { symptoms } n(\%)\end{array}$ \\
\hline Men: & & \\
$<19$ & $18(3)$ & $3(11 \cdot 1)$ \\
$20-$ & $112(19)$ & $10(8 \cdot 9)$ \\
$30-$ & $185(32)$ & $8(4 \cdot 3)$ \\
$40-$ & $170(29)$ & $20(11 \cdot 8)$ \\
$50-$ & $81(14)$ & $14(17 \cdot 2)$ \\
$>60$ & $17(3)$ & $3(17 \cdot 6)$ \\
Total & $583(100)$ & $57(9 \cdot 9)$ \\
Women: & $15(12)$ & $0(0)$ \\
$<19$ & $32(26)$ & $4(12 \cdot 5)$ \\
$20-$ & $27(23)$ & $2(7 \cdot 4)$ \\
$30-$ & $36(30)$ & $5(13 \cdot 9)$ \\
$40-$ & $9(8)$ & $0(0)$ \\
$50-$ & $1(1)$ & $0(0)$ \\
$>60$ & $120(100)$ & $11(9 \cdot 2)$ \\
Total & &
\end{tabular}

Table 3 Prevalence of asthmatic symptoms by smoking

\begin{tabular}{lrl}
\hline $\begin{array}{l}\text { Sex and } \\
\text { smoking }\end{array}$ & $n(\%)$ & $\begin{array}{l}\text { People with asthmatic } \\
\text { symptoms } n(\%)\end{array}$ \\
\hline Men: & $107(19)$ & $8(7 \cdot 5)$ \\
$\quad$ Non-smoker & $92(16)$ & $18(19 \cdot 6)^{\star}$ \\
Exsmoker & $374(65)$ & $31(8 \cdot 3)$ \\
Current smoker & $466(81)$ & $49(10 \cdot 5)^{\star}$ \\
Ex- or current smoker & & \\
Women: & $103(87)$ & $9(8 \cdot 7)$ \\
$\quad$ Non-smoker & $4(3)$ & $0(0)$ \\
Exsmoker & $12(10)$ & $2(16 \cdot 7)$ \\
Current smoker & $16(13)$ & $2(12 \cdot 5)$ \\
Ex- or current smoker & & \\
\hline
\end{tabular}

$\star \mathrm{P}<0.05 v$ non-smokers. 
non-smokers. When the data for the exsmokers were combined with those for the current smokers the prevalence of asthmatic symptoms was still significantly higher than that among the non-smokers. In the women, although the current smokers had a higher prevalence of asthmatic symptoms than the non-smokers, no significant differences were found.

RELATION BETWEEN HISTORY OF EXPOSURE TO HARD METAL AND ASTHMATIC SYMPTOMS

Table 4 summarises the prevalence of asthmatic symptoms among subjects grouped by history of exposure to hard metals. For men, there was a significant difference between the

Table 4 Prevalence of asthmatic symptoms by history of exposure to hard metal

\begin{tabular}{lrl}
\hline $\begin{array}{l}\text { Sex and exposure } \\
\text { to hard metal }\end{array}$ & $n(\%)$ & $\begin{array}{l}\text { People with asthmatic } \\
\text { symptoms } n(\%)\end{array}$ \\
\hline Men: & $263(45)$ & $16(6 \cdot 1)$ \\
$\quad$ Non-exposed & $75(13)$ & $8(10 \cdot 7)^{\star}$ \\
$\quad$ Formerly exposed & $242(42)$ & $33(13 \cdot 6)^{\star}$ \\
$\quad \begin{array}{l}\text { Currently exposed } \\
\text { Formerly or currently }\end{array}$ & $317(55)$ & $41(12 \cdot 9)^{\star}$ \\
$\quad \begin{array}{l}\text { exposed } \\
\text { Women: }\end{array}$ & $91(76)$ & $8(8 \cdot 8)$ \\
$\quad$ Non-exposed & $1(1)$ & $0(0)$ \\
$\quad$ Formerly exposed & $27(23)$ & $3(11 \cdot 1)$ \\
$\quad \begin{array}{l}\text { Currently exposed } \\
\text { Formerly or currently } \\
\text { exposed }\end{array}$ & $28(24)$ & $3(10 \cdot 7)$ \\
\hline
\end{tabular}

$\star \mathrm{P}<0.05 v$ non-exposed group.

Table 5 Prevalence of asthmatic symptoms by type of exposure to hard metal

\begin{tabular}{lrl}
\hline $\begin{array}{l}\text { Sex and type } \\
\text { of exposure }\end{array}$ & $n(\%)$ & $\begin{array}{l}\text { People with asthmatic } \\
\text { symptoms } n(\%)\end{array}$ \\
\hline Men: & $263(45)$ & $16(6 \cdot 1)$ \\
$\quad$ Non-exposed & $139(24)$ & $15(10 \cdot 8)^{\star}$ \\
$\quad$ Exposed to dust & $178(31)$ & $26(14 \cdot 6)^{\star}$ \\
$\quad$ Exposed to mist & $91(77)$ & $8(8 \cdot 8)$ \\
Women: & $16(13)$ & $2(12 \cdot 5)$ \\
$\quad$ Non-exposed & $12(10)$ & $1(8 \cdot 3)$ \\
Exposed to dust & & \\
Exposed to mist &
\end{tabular}

$\star \mathrm{P}<0.05 v$ non-exposed workers.

Table 6 Prevalence of asthmatic symptoms by atopic status (assay of serum samples)

\begin{tabular}{lrl}
\hline $\begin{array}{l}\text { Sex and } \\
\text { atopy }\end{array}$ & $n(\%)$ & $\begin{array}{l}\text { People with asthmatic } \\
\text { symptoms } n(\%)\end{array}$ \\
\hline Men: & $306(74)$ & $29(9 \cdot 5)$ \\
Non-atopic & $108(26)$ & $18(16 \cdot 7)^{\star}$ \\
$\quad$ Atopic & $45(88)$ & $6(13 \cdot 3)$ \\
Women: & $6(12)$ & $0(0)$ \\
$\quad$ Non-atopic & & \\
Atopic & & \\
$\star \mathrm{P}<0.05 v$ non-atopic subjects.
\end{tabular}

$\star \mathrm{P}<0.05 v$ non-atopic subjects.

Table 7 Prevalence of asthmatic symptoms by present exposure

\begin{tabular}{lrl}
\hline $\begin{array}{l}\text { Sex and concentration of } \\
\text { airborne cobalt }\end{array}$ & $n(\%)$ & $\begin{array}{l}\text { People with asthmatic } \\
\text { symptoms } n(\%)\end{array}$ \\
\hline Men: & & \\
0 (non-exposed) & $257(53)$ & $16(6 \cdot 2)$ \\
$0-50$ & $142(29)$ & $25(17 \cdot 6)^{\star}$ \\
$>50$ & $90(18)$ & $6(6 \cdot 7)$ \\
Women: & $91(77)$ & $8(8 \cdot 8)$ \\
0 (non-exposed) & $22(19)$ & $3(13 \cdot 6)$ \\
$0-50$ & $5(4)$ & $0(0)$ \\
$>50$ &
\end{tabular}

prevalence of the symptoms in the subjects either formerly or currently exposed to hard metal and that in the non-exposed subjects. The prevalence in the subjects in the combined group-former or current exposure to hard metal-was also significantly higher than that in the non-exposed workers. In the women, no significant differences between exposure to hard metal and prevalence of asthmatic symptoms were noted.

\section{RELATION BETWEEN TYPE OF EXPOSURE AND ASTHMATIC SYMPTOMS}

Table 5 shows the prevalence of asthmatic symptoms among the subjects grouped by exposure. The subjects exposed to dust and to mist included those formerly exposed to hard metal. Among men, those exposed to dust or to mist had a significantly higher prevalence of asthmatic symptoms than the non-exposed group. There was no significant difference between the prevalence in the group exposed to dust and that in the group exposed to mist. No similar tendency was found in the women.

\section{RELATION BETWEEN ATOPY AND ASTHMATIC} SYMPTOMS

Serum was available for assessment of atopy in $414(72 \%)$ of the 583 men and $51(43 \%)$ of the 120 women. Atopy was not assessed in some of the subjects because there was a shortage of serum after samples were used for biochemical tests such as total cholesterol and hepatic transaminase, which are indicators for diseases brought on by lifestyle and seen in middle aged people.

However, statistical comparisons between the sexes in the serum samples that were assayed for atopy did not show a significant difference in any characteristic including history of exposure to hard metal, smoking habit, and prevalence of asthmatic symptoms, although the mean age of those whose serum samples were submitted for the assay was significantly lower than that of the others in both sexes (data not shown); the prevalence of asthmatic symptoms in the group with serum samples did not differ significantly from that in the group without serum samples. Accordingly, the following analysis was made for those with serum samples for determining atopic status.

For men (table 6) the atopic group had a significantly higher prevalence of asthmatic symptoms than that did the non-atopic group.

\section{RELATION BETWEEN AIRBORNE COBALT} CONCENTRATION AND ASTHMATIC SYMPTOMS The subjects currently exposed to hard metal were divided into two groups by concentration of airborne cobalt: one group with exposure to cobalt higher than $50 \mu \mathrm{g} / \mathrm{m}^{3}$ and the other group at $50 \mu \mathrm{g} / \mathrm{m}^{3}$ or lower. Table 7 shows that for men, hard metal workers with exposure to cobalt at concentrations of $50 \mu \mathrm{g} / \mathrm{m}^{3}$ or lower had a significantly higher prevalence of asthmatic symptoms than the non-exposed subjects. Among women, those currently exposed to cobalt did not show a significantly increased prevalence of asthmatic symptoms compared with the non-exposed subjects. 
RELATION BETWEEN SENSITISATION TO COBALT AND ASTHMATIC SYMPTOMS

Serum IgE-Co measurement was performed in $86 \%$ of the men $(501 / 582)$ and $63 \%$ of the women (76/120); the sampling was incomplete for the same reason as for the atopy assay. However, statistical comparisons between those with and without serum sample assessment for IgE-Co again showed no significant difference in any characteristic including smoking, job type, and prevalence of asthmatic symptoms, except that the mean age of the women without serum IgE-Co assessment was significantly lower than that in those with serum samples.

The subjects with a score greater than the mean of the IgE-Co RAST scores plus 3SDs (1.93) were considered to be sensitised to cobalt. A total of seven subjects, all of whom were men and had a history of exposure to cobalt, were sensitised to cobalt (table 8). The prevalence of positive IgE-Co among male and female workers with current or former exposure to cobalt was $2 \cdot 4 \%$ (7/297). All of the seven subjects sensitised to cobalt had asth-

Table 8 Prevalence of RAST $>1.93$ (sensitisation to cobalt) by history of exposure to cobalt

\begin{tabular}{lrl}
\hline $\begin{array}{l}\text { Sex and history of } \\
\text { exposure to cobalt }\end{array}$ & $n(\%)$ & $\begin{array}{l}\text { People sensitised to } \\
\text { cobalt } n(\%)\end{array}$ \\
\hline Men: & & \\
Non-exposed & $218(44)$ & $0(0)$ \\
Formerly exposed & $68(13)$ & $2(2 \cdot 9)$ \\
Currently exposed & $215(43)$ & $5(2 \cdot 3)$ \\
Women: & $62(45)$ & $0(0)$ \\
Non-exposed & $1(13)$ & $0(0)$ \\
Formerly exposed & $13(42)$ & $0(0)$ \\
Currently exposed & \\
\hline
\end{tabular}

Table 9 Significant independent variables from multilogistic analysis of asthmatic symptoms on sex, age, smoking, hard metal exposure, and atopy

\begin{tabular}{ll}
\hline Factor & Odds ratio $(95 \%$ CI) \\
\hline Age $<40$ & $1 \cdot 81(1 \cdot 18-2 \cdot 76)$ \\
Age $\geqslant 40$ & $2 \cdot 77(1 \cdot 70-4 \cdot 53)$ \\
Exposure to hard metal & $1 \cdot 43(1 \cdot 02-1 \cdot 99)$ \\
Atopy & $1 \cdot 46(1 \cdot 05-2 \cdot 03)$ \\
\hline
\end{tabular}

Table 10 Significant independent variables from multilogistic analysis of asthmatic symptoms on sex, age, smoking, atopy, and concentration of airborme cobalt

\begin{tabular}{ll}
\hline Factor & Odds ratio $(95 \%$ CI $)$ \\
\hline $\begin{array}{l}\text { Age } 40 \leqslant 50 \\
\text { Age } 50 \leqslant 60\end{array}$ & $1 \cdot 73(1 \cdot 05-2 \cdot 83)$ \\
$\begin{array}{l}\text { Atopy } \\
\text { Concentration of airborne } \\
\quad \text { cobalt } 0-50 \mu \mathrm{g} / \mathrm{m}^{3}\end{array}$ & $1.01(1 \cdot 73-5 \cdot 24)$ \\
\hline
\end{tabular}

Table 11 Significant independent variables from multilogistic analysis of asthmatic symptoms on sex, age, smoking, and type of exposure to hard metal, and atopy among currently exposed subjects

\begin{tabular}{ll}
\hline Factor & Odds ratio $(95 \% \mathrm{CI})$ \\
\hline $\begin{array}{l}\text { Atopy } \\
\text { Airborne cobalt } \\
\text { concentration }\left(\leqslant 50 \mu \mathrm{g} / \mathrm{m}^{3}\right)^{\star}\end{array}$ & $2 \cdot 16(1 \cdot 31-3 \cdot 59)$ \\
$\star^{\star} v$ Airborne cobalt concentrations of $>50 \mu \mathrm{g} / \mathrm{m}^{3}$
\end{tabular}

matic symptoms and the presence of IgE-Co was significantly associated with asthmatic symptoms $(P<0.05)$. There were no women sensitised to cobalt.

\section{MULTILOGISTIC ANALYSIS OF ASTHMATIC}

SYMPTOMS ON AGE, SMOKING HABIT, EXPOSURE TO HARD METAL, AND ATOPY

As already described, significant relations between asthmatic symptoms and age (40 years old or older), positive exposure to hard metal, or atopy were noted in men, although no significant relations were found in women, possibly because of the small size of the population. Multilogistic analysis of asthmatic symptoms on those factors was conducted with combined data for all of the subjects (men and women). Smoking habit (current or exsmoker, non-smoker), a crucial lifestyle factor relating to asthmatic symptoms, was again incorporated into the analysis. Sensitisation to asthmatic symptoms, suggested by positive IgE-Co, was not taken into consideration because the population of people sensitised to cobalt was so small $(n=7)$. Table 9 shows that an age of 40 or older, current or former exposure to hard metal, and atopy were identified as significant risk factors for asthmatic symptoms among the subjects.

\section{MULTILOGISTIC ANALYSIS OF ASTHMATIC} SYMPTOMS BY AGE, SMOKING HABIT, ATOPY, AND CONCENTRATION OF AIRBORNE COBALT Multilogistic analysis of asthmatic symptoms was conducted on age, smoking habit, atopy, and concentration of airborne cobalt with data for non-exposure or current exposure to hard metal. The data for formerly exposed workers were not included because the concentrations of airborne cobalt during the period of exposure could not be obtained for all of them. The subjects were divided by individual concentrations of airborne cobalt into three groups, those with no exposure, those with exposure at $50 \mu \mathrm{g} / \mathrm{m}^{3}$ or less, and those with exposure at more than $50 \mu \mathrm{g} / \mathrm{m}^{3}$. Table 10 shows that an age of 40 or older and atopy were identified as significant risk factors. Interestingly, the lower exposure concentration of $50 \mu \mathrm{g} / \mathrm{m}^{3}$ or less rather than the higher exposure of $>50 \mu \mathrm{g} / \mathrm{m}^{3}$ was identified as a significant risk factor.

\section{MULTILOGISTIC ANALYSIS OF ASTHMATIC} SYMPTOMS ON EXPOSURE TYPE

To test the hypothesis that the mist of coolants used for grinding hard metal has greater potency in inducing asthma than the dust of hard metal, multilogistic analysis of asthmatic symptomss was carried out with data from the currently exposed workers only for type of exposure (dust or mist) as well as the independent variables already mentioned. Table 11 shows that although atopy and the lower level of exposure to cobalt $\left(<50 \mu \mathrm{g} / \mathrm{m}^{3}\right)$ were again significantly related to asthmatic symptoms, exposure to mist was not associated with any increase of the frequency of asthmatic symptoms in comparison with exposure to hard metal dust. 


\section{Discussion}

Some of our colleagues have reported population based studies conducted at the same hard metal corporation as we examined in the present study indicating that exposure to hard metal in combination with smoking may increase total IgE..$^{21}$ Shirakawa et al also reported that IgE-Co RAST score increased with the exposure to cobalt, showing a multiplicative effect of concentration of airborne cobalt with duration of exposure. ${ }^{22}$ Although the total IgE concentrations in a part of the population may include specific IgE against inhalant allergens such as mites and cobalt allergen, an increase in total IgE titre does not necessarily indicate the start of allergic disease or sensitisation to particular allergens. In these studies neither allergic diseases of the bronchial tree nor allergic respiratory symptoms were chosen to evaluate the outcome after exposure to hard metal.

Irrespective of the dose-response relation found between the exposure dose of cobalt and specific IgE antibodies to cobalt, a significantly high RAST score $(>1.9)$ of IgE-Co was found in only $10(2 \cdot 0 \%)$ of the 489 subjects of the study performed by Shirakawa and Morimoto in $1989 . .^{22}$ These 10 subjects included all of the seven men with positive IgE-Co found in the current study, performed in 1987, and involved three newcomers recruited later. As increased total $\operatorname{IgE}$ or increased IgE-Co, especially at the upper end of the normal range, does not necessarily correspond to the appearance of allergic disease or symptoms, the asthmatic symptoms were selected in the present study to indicate the health effect of exposure to hard metal; the results suggested that exposure to hard metal increases the prevalence of asthma.

We previously showed, among workers currently or formerly exposed to hard metal, a prevalence of hard metal asthma of $5.6 \%$ and a cumulative incidence of $3.6 \% .^{46}$ In the present study, the asthmatic symptoms, unlike asthma diagnosed on the basis of clinical and physiological definition as in the previous studies already cited, were defined according to the subjects' responses to the respiratory questionnaire given by trained interviewers. The prevalence of asthmatic symptoms was found to be $13 \cdot 1 \%(41 / 314)$ among currently or formerly exposed workers, which was almost twice the reported prevalence of hard metal asthma. The criteria for hard metal asthma used in the previous studies might have resulted in false negative results. By contrast, the asthmatic symptoms assessed in the present study do not necessarily indicate asthma, and the incidence of false positive results may accordingly be increased in comparison with clinically diagnosed hard metal asthma. However, the results obtained with a respiratory questionnaire, such as that by the MRC, can be compared with those of other studies adopting the same or a similar method for an epidemiological purpose.

Although asthma, defined according to the American Thoracic Society and our previous studies, was reported to be rare in French hard metal plants, ${ }^{7}$ Alexandersson and Swensson in Sweden showed that workers who were exposed to cobalt at the mean concentration of $60 \mu \mathrm{g} / \mathrm{m}^{3}$ when handling hard metal dust complained of chest tightness significantly more often (38\%; 24 of 63 subjects) than controls (none of 63 subjects). ${ }^{8}$ Thirty three per cent of workers (10/33) exposed to cobalt at concentrations ranging from 5 to $10 \mu \mathrm{g} / \mathrm{m}^{3}$, according to the same authors, had the symptoms, although the prevalence was not significantly higher than that in controls $(0 / 33)$. Sprince $e t$ al stated that the prevalence of work related wheeze was $9 \cdot 2 \%$ among those exposed to cobalt at concentrations of $50 \mu \mathrm{g} / \mathrm{m}^{3}$ or less and that it remained stable at around $17 \%$ among those exposed to cobalt at greater concentrations. ${ }^{9}$ In a study of workers employed in producing cobalt, Roto found that asthma was provoked after exposure to cobalt even at concentrations under $100 \mu \mathrm{g} / \mathrm{m}^{3}$, the Finnish threshold limit value, and that wheeze, defined on the same basis as in the present study, was found in $28 \% .^{15}$ The prevalence of asthmatic symptoms found in the present study among hard metal workers with past or present exposure to hard metal $(12.9 \%, 44 / 342)$ seems to be comparable with these reports.

The serum could be analysed to evaluate the atopic status in $74 \%$ of the men, but only in $42 \%$ of the women. We think that the use of the multivariate model for evaluation in these subjects is acceptable, because the subgroup whose serum samples were and were not analysed showed no difference in any characteristic, including the prevalence of asthmatic symptoms, except for mean age. It thus seems reasonable to accept the validity of the results of the model indicating that atopy and IgE-Co are risk factors for hard metal asthma.

The multilogistic analysis clearly showed that age, atopy, and exposure to hard metal were risk factors associated with asthmatic symptoms. This evidence suggests that the asthmatic symptoms, probably associated with asthma in many people, are work related. Atopy has been shown to be a strong predisposing factor for various types of occupational asthma, ${ }^{23}$ and this phenomenon was found in hard metal asthma.

Explanation is needed to interpret the result that being aged 40 or older may be a probable risk factor for hard metal asthma. It is well known that so-called intrinsic asthma occurs mainly in middle aged people. Aging might aid the development of asthma of this type, possibly triggered by exposure to hard metal. In a previous study we found that about $60 \%$ of subjects with hard metal asthma (18/31) developed asthma within one year of employment, at whatever age they were recruited by the corporation. We were aware that the corporation had employed many people about 10 years before the time of the present study and that many of these employees had reached the age of 40 during the interim. Recently, we have also noted that the number of atopic people in the younger generation has increased in Japan, and that asthma develops in some 
people in their 20s after employment at the hard metal corporation. A prospective study would be useful in examining this possible effect of age as a risk factor for hard metal asthma.

Smoking is also known to be a very potent risk factor not only for atopic allergic asthma but also for occupational asthma. ${ }^{23}$ However, we found no significant relation of smoking to asthmatic symptoms among our subjects. According to Japanese nationwide statistics, almost $60 \%$ of all adults are smokers, whereas only $14 \%$ of women smoke. The high percentage of smokers among non-asthmatic subjects as well as asthmatic subjects might mask the effects of smoking on the asthmatic symptoms as evaluated by multilogistic analysis.

The concentrations of airborn cobalt were measured for all of the people from air samples taken on at least two separate working days. Thus the mean values of cobalt concentrations in the air used for analysis were representative of the individual cobalt exposures. A noticeable finding was that not a high but a low concentration of exposure to cobalt (below 50 $\mu \mathrm{g} / \mathrm{m}^{3}$ ) was a risk factor for hard metal asthma (tables 10 and 11). This evidence does not support a dose response relation between hard metal asthma and concentrations of airborn cobalt.

By contrast, a positive dose response relation between respiratory symptoms (chest tightness, work related wheeze, and dyspnoea on exertion) and concentrations of airborn cobalt was found in cross sectional studies at hard metal plants $^{89}$ and a cobalt refinery plant. ${ }^{14}$ Compared with the non-exposed subjects, the subjects exposed to cobalt at the low level in these studies had increased frequencies of the symptoms. First of all, it should be pointed out that the asthmatic symptoms adopted by the authors as a health effect indicator may differ from the symptom of work related wheeze examined by Sprince $e t a l^{9}$ or the complaint of dyspnoea on exertion assessed by Swennen et al. ${ }^{14}$ Secondly, the distribution of atopy, which has quite a strong effect on occupational asthma, was not considered in these studies. Finally, the age distribution of the subjects should be taken into consideration in interpretation of the doseresponse relation.

The question of whether the subjects had previously been exposed to cobalt at higher levels than those at the time of the study could be considered in a careful, well designed prospective study. Respiratory disorders including dyspnoea and irritation of the mucous membranes have also been found among workers producing blue dyes ${ }^{24}$ and glass bangles ${ }^{25}$ containing cobalt. The biological role of cobalt in these disorders should be carefully studied in relation to the concentrations in the work environment.

We thank Dr T Shirakawa, Department of Hygiene and Preventive Medicine, Osaka University School of Medicine, for his kind offer of data on IgE-Co.

1 Bech AO, Kipling MD, Heather JC. Hard metal disease. $B r$ F Ind Med 1962;19:239-52.

2 Coates EO, Watson JHL. Diffuse interstitial lung disease in tungsten carbide workers. Ann Intern Med 1971;75: 709-16.

3 Coates EO, Sawyer HJ, Rebuck JW, Kvale PA, Sweat LW. Hypersensitivity bronchitis in tungsten carbide workers. Chest 1973;64:390.

4 Kusaka Y, Yokoyama K, Sera Y, Yamamoto S, Sone S, Kyono $\mathrm{H}$, et al. Respiratory diseases in hard metal workers: an occupational hygiene study in a factory. $\mathrm{Br} \mathcal{F}$ Ind Med 1986;43:474-85.

5 Shirakawa T, Kusaka Y, Fujimura N, Goto S, Kato M, Heki S, Morimoto K. Occupational asthma from cobalt sensitivity in workers exposed to hard metal dust. Chest sensitivity in work

6 Kusaka Y, Fujimura N, Morimoto K. Hard metal disease: epidemiology and pathogenesis. In: Kobayashi S, Bellant JA, ed. Advances in asthmology 1990. Amsterdam Elsevier, 1991:271-6.

7 Meyer-Bisch C, Pham QT, Mur J-M, Massin N, Moulin J$\mathrm{J}$, Teculescu D, et al. Respiratory hazards in hard meta workers: a cross sectional study. $\mathrm{Br} \mathcal{F}$ Ind Med 1989, 46:302-9.

8 Alexandersson R, Swensson Ä. Studies on the pulmonary reaction of workers exposed to cobalt in the tungsten carbide industry. Arh Hig Rada Toksikol 1979;30(suppl): bide ind 61 .

9 Sprince NL, Oliver C, Eisen EA, Greene RE, Chamberlin RI. Cobalt exposure and lung disease in tungsten carbide production. A cross-sectional study of current workers. Am Rev Respir Dis 1988;138:1220-6.

10 Gheysens B, Auwerx J, Van Den Eeckhout A, Demedts M Cobalt-induced bronchial asthma in diamond polishers. Chest 1985;88:740-4.

11 Van Custem EJ, Ceuppens JL, Lacquet LM, Demedts $M$ Combined asthma and alveolitis induced by cobalt in a diamond polisher. Eur f Respir Dis 1987;70:54-61.

12 Gennart JPh, Lauwerys $\mathrm{R}$. Ventilatory function of workers exposed to cobalt and diamond containing dust. Int Arch Occup Environ Health 1990;62:333-6.

13 Nemery B, Casier P, Roosels D, Lahaye D, Demedts $M$. Survey of cobalt exposure and respiratory health in diamond polishers. Am Rev Respir Dis 1992;145:610-6.

14 Swennen B, Buchet J-P, Stanescu D, Lison D, Lauwerys R Epidemiological survey of workers exposed to cobalt oxides, cobalt salts, and cobalt metal. $\mathrm{Br} \mathcal{F}$ Ind $\mathrm{Med}$ 1993;50:835-42.

15 Roto P. Asthma, symptoms of chronic bronchitis and ventilatory capacity among cobalt and zinc production workers. Scand 7 Work Environ Health 1980;6(suppl 1): work

16 Sjögren I, Hillerdal G, Andersson A, Zetterström O. Hard metal lung disease: importance of cobalt in coolants. metal lung disease: impo

17 Kusaka Y, Yokoyama K, Sera Y, Shirakawa T, Goto S, Morimoto K. Evaluation of the self-administered respiratory questionnaire recommended by the Japanese Labour Ministry based on the standardized interviewer-administered BMRC Questionnaire. fpn Ind Health 1989;31: 415-20.

18 Medical Research Council Committee on the Aetiology of Chronic Bronchitis. Standardized questionnaire on respiratory symptoms. $B M 71960 ; 2: 1665$.

19 SAS Institute. SAS/STAT User's guide, ed 6.08. Cary:SAS Institute, 1993.

20 Shirakawa T, Kusaka Y, Morimoto K. Combined effect of smoking and occupational exposure to hard metal on total IgE antibodies. Chest 1992;101:1569-76.

21 Shirakawa $T$, Morimoto $K$. Lifestyle factor on total IgE. Allergy 1991;46:561-9.

22 Shirakawa T, Morimoto K Effect of lifestyle on levels of specific IgE antibodies. Allergy 1993;48:177-82.

23 Chan-Yeung M, Lam S. Occupational asthma (state of the art). Am Rev Respir Dis 1986;133:686-703.

24 Raffn E, Mikkelsen S, Altman DG, Christensen JM, Groth $S$. Health effects due to occupational exposure to cobalt blue dye among plate painters in a porcelain factory in blue dye among plate painters in a porcelain factory in Denmark. Scand f Work Environ Health 1988;14:378-84

5 Rastogi SK, Gupta BN, Husain T, Chandra H, Mathur N, Pangtey BS, et al. A cross-sectional study of pulmonary function among workers exposed to multimetals in
glass bangle industry. Am $\mathcal{F}$ Ind Med 1991;20:391-9. 